\title{
Impact of web accessibility barriers on users with a hearing impairment
}

\author{
Afra Pascual ${ }^{a}$, Mireia Ribera ${ }^{b} \&$ Toni Granollers ${ }^{c}$ \\ ${ }^{a}$ GRIHO Research Group, Polytechnic School, University of Lleida, Lérida, Spain apascual@diei.udl.cat \\ ${ }^{b}$ Adaptabit, research group. Department of Information Science, University of Barcelona, Barcelona, Spain.ribera@ub.edu \\ ${ }^{c}$ GRIHO research group, Polytechnic School, University of Lleida, Lérida, Spain. antoni.granollers@udl.cat
}

Received: February $18^{\text {th }}, 2015$. Received in revised form: March $16^{\text {th }}, 2015$. Accepted: September $26^{\text {th }}, 2015$

\begin{abstract}
Several user tests were carried out on people with a hearing impairment to evaluate the impact of different web accessibility barriers on two similar web sites, one accessible and the other not accessible. The tests' focus was to analyze users' moods when faced with different accessibility barriers. Results show "complex text" and "multimedia content without text alternative" as the most critical barriers for users with this profile. Our investigation contributes to a better understanding of users when confronting accessibility barriers, and to emphasize the need of web content authors to use plain language and to provide captions and sign language alternatives in video content
\end{abstract}

Keywords: Web Accessibility, barriers, WCAG 2.0, Communicability, Accessible content, Deaf users, hearing impairment, User test.

\section{Impacto de las barreras de accesibilidad web en usuarios con discapacidad auditiva}

\section{Resumen}

Se realizaron pruebas de usuarios a personas con discapacidad auditiva evaluando el impacto que las diferentes barreras de accesibilidad causan en este tipo de usuarios. El objetivo de recoger esta información fue para comunicar a personas que editan contenido en la Web de forma más empática los problemas de accesibilidad que más afectan a este colectivo, las personas con discapacidad auditiva,y así evitar las barreras de accesibilidad que potencialmente podrían estar creando. Como resultado, se observa que las barreras que causan mas impacto a usuarios con discapacidad auditiva son el "texto complejo" y el "contenido multimedia" sin alternativas. En ambos casos los editores de contenido deberían tener en cuenta vigilar la legibilidad del contenido web y acompañar de subtítulos y lenguaje de signos el contenido multimedia.

Palabras clave: Accesibilidad Web, Barreras, WCAG 2.0, Comunicabilidad, Con-tenido accesible, Usuarios con discapacidad auditiva, Test de usuarios.

\section{Introduction}

Nowadays, a significant number of Internet users have a high level of digital literacy [1]. However, users with disabilities affecting language acquisition may have problems understanding web content. According to the World Health Organization, more than $5 \%$ of the population has a hearing impairment or suffers from hearing loss [2].

Hypoacusia, can be classified by different levels depending on what sounds a person is able to hear: with mild hearing loss the person is able to hear sounds louder than 21 to $40 \mathrm{~dB}$, in moderate hearing loss they hear sounds louder than 40 to $69 \mathrm{~dB}$, in severe hearing loss they only hear sounds above 71 to $90 \mathrm{~dB}$, and in profound hearing loss or deafness they do not hear sounds unless they are louder than $90 \mathrm{~dB}$ People with mild to severe hearing loss are likely to be able to speak clearly and to benefit from hearing aids. People with profound or total hearing loss communicate through lip

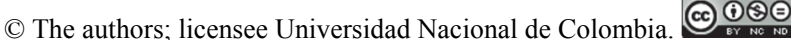


reading, and talk by speech or through sign language.

The onset of hearing loss is also important and it can be defined as: (a) prelocutive or prelingual hearing loss, when it appears before the age of two, (b) perilocutive when it appears between two to four years, and (c) postlocutive when it appears at a later stage in life. In both prelocutive and perilocutive hearing loss, speech and language development are hindered. In postlocutive hearing loss, speech can progressively suffer from phonetic or prosodic alterations [3].

When web developers and content authors think about a web site being accessible, they usually think about it being perceivable, and within this requirement, at best they know that video content should have captions. They also think about it being operable or robust, but in most cases they forget the understandable principle from the WCAG guidelines. This principle is paramount for people with language difficulties. Some authors [4],[5] state that Web Content Accessibility Guidelines (WCAG) 2.0 [6] are not insistent enough on the understandable principle, while they consider it to be the most critical requirement for users with hearing or cognitive disabilities and even for foreign people who have not mastered the language in which the web is written [7]. Globally, $28 \%$ of WCAG 2.0 success criteria is related to users with hearing impairments, $66 \%$ of them being level A, 17\% level AA and 17\% level AAA [8].

The user tests presented in this article correspond to the third stage of the research, which is aimed at collecting empirical data related to the moods and the user experience of people with disabilities while they interact with web content that has accessibility barriers. Previous stages include people with cognitive disabilities (first stage) [9] and visual disabilities (second stage) [10], and there is an ongoing user test (fourth and last stage) being conducted with people with motor impairments. All of them browsed the same web content, but different barriers were tested for in each group.

We define "accessibility barrier" as any condition that makes it difficult for people with disabilities or special needs to achieve a goal while they are browsing a website, even if they use the appropriate assistive technology [11]. In contrast to the content with barriers, content with good accessibility improves efficiency and promotes autonomy for users with disabilities [12], increasing their welfare and quality of life [13],[14].

This article collects and analyzes empirical information of a group of users with hearing loss while browsing two websites with similar content but different levels of accessibility. One of the sites was built with many accessibility barriers (NA-site), while the other is completely accessible (A-site). The final aim of the research is to obtain the degree of impact for each accessibility barrier in order to communicate it when an error is detected in a web 2.0 authoring scenario. The focus is on emotions because regular web 2.0 users do not have expertise in technical accessibility [15], and we want them to empathize with their potential users.

Current accessibility evaluation tools offer their results in a very technical language [16], which users without a deep knowledge of accessibility often find difficult to understand.
The authors believe that it is possible to improve error communication by having empathy with the user. We intend to transmit users' experiences to web 2.0 authors when they submit new content in a blog, for example, and they make an error. As an example, when a user embeds a video without captions, instead of saying: "1.2.1. Audio-only and Videoonly (Prerecorded): For prerecorded audio-only and prerecorded video-only media, the following are true, except when the audio or video is a media alternative for text and is clearly labeled as such: (Level A)" [6], we will (by means of the interface) tell them "This video does not include captions", and we will show a deaf user saying "Without captions I can not understand it!" With messages like this we will try to improve non-technical authors' understanding and awareness of accessibility needs and problems.

Emotions can be classified by three continuous dimensions [17]: valence, which encompasses values from nice to nasty; activation, ranging from calm to excited; and power, characterized by strong and weak. Primary emotions have positive (joy, happiness, etc.) or negative (anger, fear, sadness, etc.) valence and, depending on the emotion's intensity, its degree of activation will go from "calm" (boring) to "excited" (tense).

There are several techniques for measuring emotions classified into objective and subjective techniques. The objective techniques are mainly designed to analyze the bodily changes of a person, by means of studying facial expressions or measuring bodily reactions, such as heart beat or dilated pupils. According to the James-Lange theory [18], different emotions produce changes in the body that can not be controlled.

The subjective techniques measure the feelings and emotions of a user through questionnaires, interviews and selfreports. They provide information about user experience when performing a specific task. Nevertheless, they are based on a subjective perception and the result may be biased by the user's own interests and desires. Related to this technique, there are two different types of self-reports: verbal and non-verbal. In verbal reports the participant uses words to indicate the perceived emotion, as for example, in [19] and [20]. In non-verbal reports, a set of images representing the variety of emotions are shown to the users, who only have to point out which image represents the particular perceived emotion, for example in [22-24].

Because this last option is easier for deaf users, in our study we have chosen a subjective technique based on nonverbal language.

The article is organized as follows: section 2 introduces the experimental framework used to evaluate users' moods, section 3 details the results and findings ordered by accessibility barrier, and finally, section 4 presents our conclusions.

\section{Experimental framework}

We built two websites using WordPress 1 containing touristic information about a city. The accessible site (Asite2) was built following the methodology described in [25], which grants a high level of accessibility when working with

\footnotetext{
1 Wordpress. https://es.wordpress.com/
} 
Pascual et al / DYNA 82 (193), pp. 233-240. October, 2015.

Table 1.

$\underline{\text { List of tasks, elements and WCAG } 2.0 \text { criteria. }}$

\begin{tabular}{|c|c|c|}
\hline Task & NA-site & A-site \\
\hline T1. Looking up a podcast & $\begin{array}{l}\text { Non-transcribed audio } \\
\text { (WCAG } 2.0 \text { success } \\
\text { criteria: } 1.2 .1,1.2 .2,1.2 .3 \text {, } \\
1.2 .4,1.2 .5,1.2 .9 \text { ) }\end{array}$ & Audio and transcript \\
\hline $\begin{array}{l}\text { T2. Looking up data in a } \\
\text { graph }\end{array}$ & $\begin{array}{l}\text { Complex image (WCAG } \\
2.0 \text { principle: } 3 \text { ) }\end{array}$ & Simple image \\
\hline $\begin{array}{l}\text { T3. Looking up data in a } \\
\text { data table }\end{array}$ & $\begin{array}{l}\text { Complex words in a data } \\
\text { table (WCAG } 2.0 \text { success } \\
\text { criteria: } 3.1 .3,3.1 .4 \text { ) }\end{array}$ & $\begin{array}{l}\text { Simple text in a data } \\
\text { table }\end{array}$ \\
\hline T4. Playing a video file & $\begin{array}{l}\text { Video without captions } \\
\text { (WCAG } 2.0 \text { success } \\
\text { criteria: } 1.2 .1,1.2 .2,1.2 .3 \text {, } \\
1.2 .4,1.2 .5,1.2 .7,1.2 .8, \\
1.2 .9 \text { ) }\end{array}$ & $\begin{array}{l}\text { Video with captions } \\
\text { and sign language }\end{array}$ \\
\hline $\begin{array}{l}\text { T5. Looking up } \\
\text { information of a } \\
\text { monument }\end{array}$ & $\begin{array}{l}\text { Complex text (WCAG } 2.0 \\
\text { success criteria: } 3.1 .3 \text {, } \\
3.1 .5 \text { ) }\end{array}$ & Simple text \\
\hline
\end{tabular}

Source: The author

content management systems. The WordPress settings were configured to have the top level of accessibility: we used accessible templates (TwentyTenFive3) and (Accessiblefive4), we used raw HTML code when the automatic code was not compliant with accessibility specifications, and we installed extensions to improve accessibility in several elements. We also used an audio plugin (Accessible Audio Player (AAP)5 and an accessible video player (CCPlayer6).

The non-accessible site (NA-site7) was built with the standard settings in WordPress. We used the default template (Twenty Twelve) and we did not install any extension or any additional accessibility feature. The content was added with cut and paste from a word processing application and images were added by dragging them to the WordPress editor.

Before the user test, each web site's level of accessibility was checked against WCAG guidelines using automatic evaluators (eXaminator8 and TAW9) and by a manual review with the WAT10 support on the IExplorer and Web Developer toolbar, 11 using Firefox, and following the W3C evaluation methodology [26] guidelines. Taking into account the importance of language [27], we also manually analyzed the complexity of the text and calculated the Flesh-Kincaid Spanish score12. The result was that the NA-site showed many accessibility issues relating to the template and the content added with text editor. It also failed in the HTML and CSS validations 13 , and it had a $60 \%$ (normal text) readability index. In contrast, the A-site did not display accessibility barriers, and it had an $80 \%$ (easy to read text) readability index.

We then devised the tasks to be carried out by users, based on barriers affecting people with hearing impairments. In

\footnotetext{
3 TwentyTenFive: http://www.twentytenfive.com/

4 AccessibleFive: http://accessible.sprungmarker.de/2011/04/accessiblefive/

5 Accessible Audio Player (AAP). http://www.terrillthompson.com/music/aap/

6 CCPlayerhttp://www.ccplayer.com/

7 NA-site: http://193.144.12.82/accesibilidad/wpA

8 Examinator: http://examinator.ws/
}

Table 2 .

User characteristics. W: Woman, M: Man, SL: Signed Language, O: Orally

\begin{tabular}{|c|c|c|c|c|c|c|}
\hline & Id & Sex & Schooling & Speak & Language & Web Experience \\
\hline \multirow{3}{*}{$\begin{array}{l}\stackrel{\circlearrowright}{0} \\
\frac{0}{2} \\
z\end{array}$} & U01 & $\mathrm{W}$ & $\begin{array}{l}\text { Elementary } \\
\text { school }\end{array}$ & SL & Spanish & From 1 to 5 years \\
\hline & U02 & M & High school & SL & Spanish & From 1 to 5 years \\
\hline & U03 & M & $\begin{array}{l}\text { Elementary } \\
\text { school }\end{array}$ & SL & Spanish & From 1 to 5 years \\
\hline \multirow{7}{*}{ 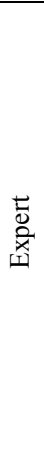 } & U04 & $\mathrm{M}$ & High school & SL & Spanish & Longer than 5 years. \\
\hline & U05 & M & $\begin{array}{c}\text { Elementary } \\
\text { school }\end{array}$ & SL & $\begin{array}{c}\text { Spanish } \\
\text { and Catalan }\end{array}$ & Longer than 5 years \\
\hline & U06 & M & High school & $\mathrm{SL}$ and $\mathrm{O}$ & $\begin{array}{c}\text { Spanish } \\
\text { and Catalan }\end{array}$ & Longer than 5 years \\
\hline & U07 & W & $\begin{array}{c}\text { Elementary } \\
\text { school }\end{array}$ & SL & $\begin{array}{c}\text { Spanish and } \\
\text { Catalan }\end{array}$ & Longer than 5 years \\
\hline & U08 & W & $\begin{array}{c}\text { Elementary } \\
\text { school }\end{array}$ & SL & Spanish & Longer than 5 years \\
\hline & U09 & Man & $\begin{array}{l}\text { Elementary } \\
\text { school }\end{array}$ & SL & Spanish & Longer than 5 years \\
\hline & U10 & W & $\begin{array}{c}\text { Elementary } \\
\text { school }\end{array}$ & SL & Spanish & Longer than 5 years \\
\hline
\end{tabular}

Source: The author

Table 1 each task is described with its associated content and related WCAG 2.0 success criteria. To create the tasks and decide the elements involved in each of them, we followed the methodology described in [28].

\subsection{Participants}

A total of 14 people participated in the user test, 10 of them with total deafness and 4 with moderate hearing loss. As the results of users with moderate hearing loss were repeated and amplified by users with total deafness, in this article we only include the results of the severely deaf users, as they show most clearly the impact of barriers. Participants (on average 46 years old) were grouped according to their experience level: novice (3 users) and experts (7 users). A profile of each user is described in Table 2.

\subsection{Methodology}

The user test was undertaken following the evaluation methodology proposed by Rubin [29] and Nielsen [30].

All user tests took place in the "casa de las personas sordas" (deaf people's houses) in an isolated room with a wifi connection, on a personal computer running Windows 7 Operating System (Service Pack 3) equipped with speakers, on a standard keyboard, and with a 2-button mouse with a scroll wheel.

After the user gave his consent, the session was recorded with the computer webcam. $50 \%$ of the users denied consent to record their face and $10 \%$ of them even denied consent to

\footnotetext{
9 Test de accesibilidad Web (TAW) http://www.tawdis.net/

${ }^{10}$ WAT de IExplorer: http://www.paciellogroup.com

${ }^{11}$ Firefox Web Developer: http://chrispederick.com/work/web-developer/

${ }^{12}$ Readability index calculator (Fernández-Huerta para español) http://www.standards-schmandards.com/exhibits/rix/

${ }^{13}$ World Wide Web Consortium.(2006). The W3C markup validation service. http://validator.w3.org/
} 


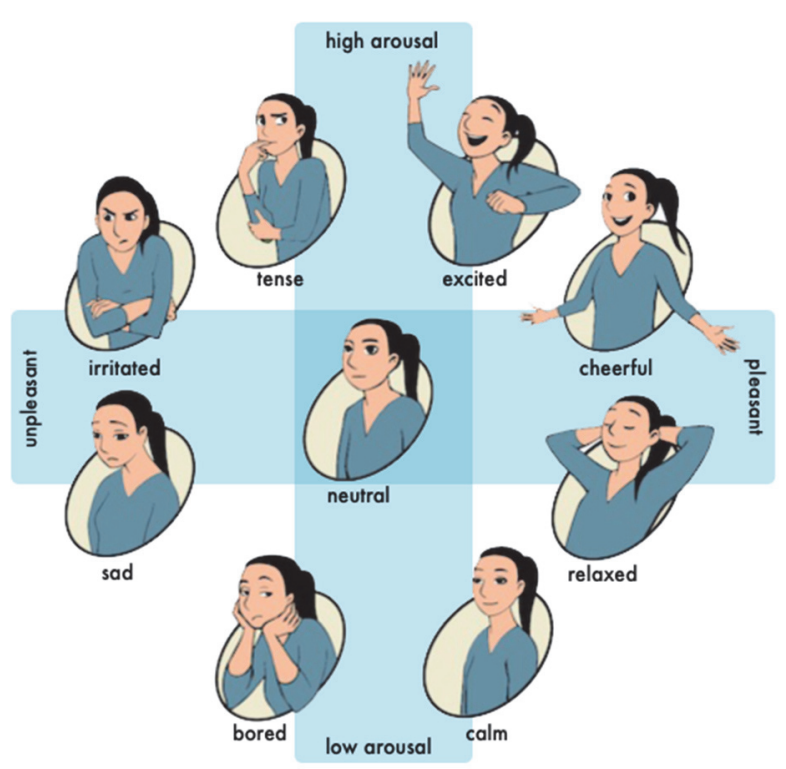

Figure 1. The Pic-A- Mood characters.

Source: http://studiolab.ide.tudelft.nl/studiolab/pmri/

record the audio of the test because they did not feel comfortable with it. Morae $3.0^{14}$ software was used to record users' interaction with both websites, and, if allowed, the same software was used to analyze facial expressions and users comments. When recording was not allowed, the observer made annotations that were subsequently analyzed.

Before the test, a questionnaire was administered to obtain a profile of the user. Participants were also asked to report on previous experiences interacting with either accessible or non-accessible websites. In the test, every user completed task 1 to task 5 on A-site and also on NA-site. Tasks were randomly ordered to avoid the effects of learning or fatigue. Tasks were written in plain language and were given to participants asking them if they had any doubts. For each task, measures were undertaken to ensure efficiency and effectiveness. After each task, the user was asked about his/her mood. To evaluate the mood in the pre-task and posttask test, we choose "Pic-a-Mood-PictorialMood-Reporting Instrument" [24] emocards (Fig. 1). In these kinds of evaluations the user chooses from among a set of characters -each one accurately and unambiguously representing a mood (in our case, tense, irritated, sad, bored, neutral, calm, relaxed, cheerful, excited)-one specific character that fits the users' current mood.

\section{Results}

\subsection{Pre-test questionnaire}

Fig. 2 shows that all participants reported a negative mood when they visit websites with accessibility problems (Fig. 2a), and a more positive mood when they interact with websites that have no accessibility problems (Fig. 2b).

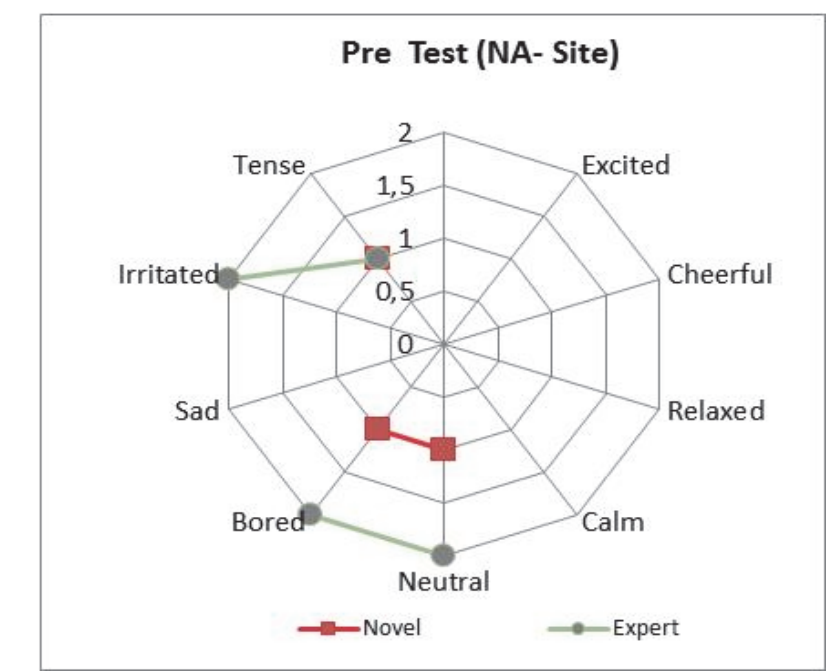

Figure 2a. Emotional evaluation in pre-test questionnaire (NA-website). Source: The author

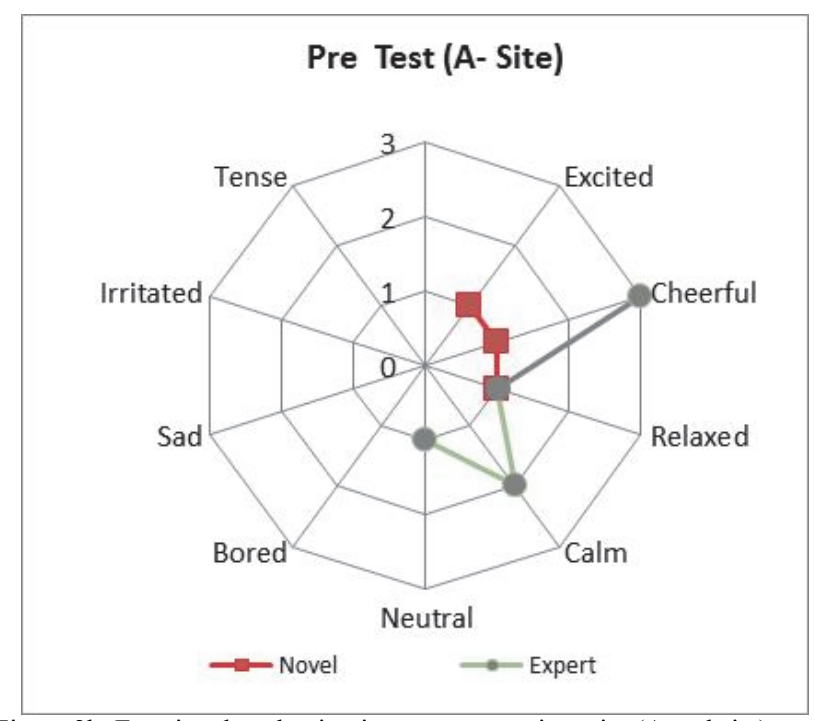

Figure 2b. Emotional evaluation in pre-test questionnaire (A-website). Source: The author

\subsection{Barriers}

The results are organized by barrier to distinguish their relative impact to users. For each barrier a table (see below) shows average task duration (in minutes), percentage of users who completed the associated task, and the emocard selected by users identifying their mood on the Non Accessible Web Site (NA) and on the Accessible Web Site (A).

\subsubsection{Barrier "No captions for audios"}

This barrier was evaluated in task 1 (T1): Looking up a podcast. This task was impossible in NA-site as there was no script for the audio content. Users did not bother to press the

\footnotetext{
${ }^{14}$ Software Morae. http://www.techsmith.com/morae.asp
} 
Table 3.

Results of Task 1. Barrier "No captions for audios"

\begin{tabular}{|c|c|c|c|c|c|}
\hline $\begin{array}{l}\text { Web } \\
\text { site }\end{array}$ & Users grou & & Time & $\begin{array}{c}\text { Task } \\
\text { completion } \\
\text { rate }\end{array}$ & Emocard \\
\hline NA & $\begin{array}{l}\text { 1.1.1.1.1.1.1 } \\
\text { Expert }\end{array}$ & Novice & $\begin{array}{l}0.36 \\
0.46\end{array}$ & $0 \%$ & $\begin{array}{c}\text { Sad (3) } \\
\text { Neutral } \\
(7) \\
\end{array}$ \\
\hline A & $\begin{array}{r}1.1 .1 .1 .1 .1 .2 \\
\text { Expert }\end{array}$ & Novice & $\begin{array}{l}1.18 \\
0.91\end{array}$ & $100 \%$ & Neutral \\
\hline
\end{tabular}

Source: The author

play button, as they knew they would be unable to hear the audio.

Conversely, on A-site, $100 \%$ of users used the audio transcript to get the desired information, and although an audio record was offered, no user played it.

On this task, in the NA-site, three users choose the mood "sad", and seven choose "neutral", while in the A-site, all of them choose "neutral". These results are detailed in Table 3.

After the task, one user stated "as I know that I will not be able to hear the audio, I don't bother playing it", and another said "I am very grateful to those web pages that took us into account and that offer a transcript in addition to the audio!"

\subsubsection{Barrier "Video with no captions"}

This barrier was evaluated in Task 4 (T4): "Playing a video". This task, which was impossible to complete in NAsite was included to assess the mood in a common situation: the user browses a web site with an audio-visual content without a textual alternative. No user could finalize the task in the NA-site, because although the video showed a presenter in the foreground and users could read his lips, the camera occasionally pointed at the audience and it was impossible to understand the complete discourse. In this task all users described their mood as "irritated".

Conversely, on the A-site $100 \%$ of the users could finalize the task as they were able to understand the video through the captions or the sign language (Fig.3). All users displayed a great joy (they choose the "excited" emocard) when they were able to completely understand the video. The results from this task are presented in Table 4. Some user comments were also annotated and can be used as qualitative feedback: "I get very nervous when captions are not synchronized with the image", "very often I have no time to read the captions as they go too fast, and I also have problems understanding some words", "even when there are captions, I'm very glad to see a sign-language interpreter because, then, I understand all the video. Otherwise I only get the outline", "I prefer captions as there are different sign languages for Catalan and Spanish and sometimes I don't understand the Catalan language very well".

\subsubsection{Barrier "Complex text"}

This barrier was assessed in task 3 (T3): Looking up data in a data table, and in task 5 (T5): Looking up information in a monument.

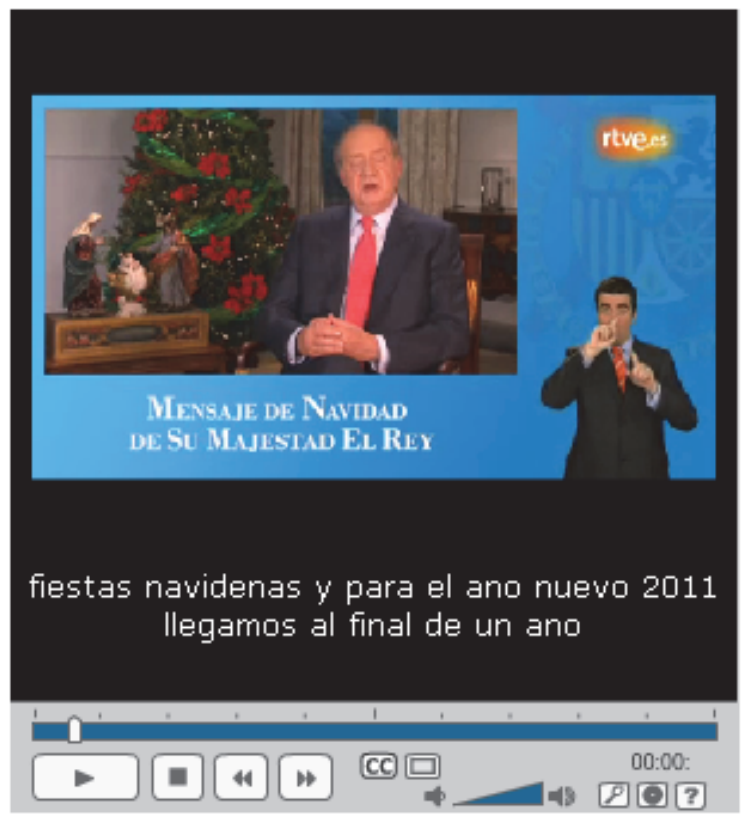

Figure 3. Video test from task 4 on A-site.

Source: rtve.es

Table 4.

Results of Task 4. Barrier "Video with no captions"

\begin{tabular}{|c|c|c|c|c|c|}
\hline $\begin{array}{l}\text { Web } \\
\text { site }\end{array}$ & Users grou & & Time & $\begin{array}{c}\text { Task } \\
\text { completion } \\
\text { rate }\end{array}$ & Emocard \\
\hline NA & $\begin{array}{c}\text { 1.1.1.1.1.1.3 } \\
\text { Expert }\end{array}$ & Novice & $\begin{array}{l}0.72 \\
1.16\end{array}$ & $0 \%$ & Irritated \\
\hline A & $\begin{array}{l}\text { Novice } \\
\text { Expert }\end{array}$ & & $\begin{array}{l}0.97 \\
1.10\end{array}$ & $100 \%$ & Excited \\
\hline
\end{tabular}

Source: The author

The data tables on both sites displayed similar information, but the wording was more difficult in the NAsite. For example, in the NA-site there was a column called "total precipitation", while the same data was named "total rainfall" in the A-site. The rainfall was presented in quarters, which were indicated by words (January-March, April-June, etc.) in the A-site, but by anon-common abbreviations in the NA-site. The NA-site had also a color code indicating rainfall. In the T2 task, users had to indicate the month with higher rainfall, and they mostly failed in the NA-site despite the color code.

Task 5 evaluated complexity of contents. In the NA-site the text was complex, with difficult words and complex syntactic structures, with long sentences and a lot of subordinate clauses. Users were asked about some information indirectly given by the web content; a correct answer implied understanding of the wording. In the A-site, text was reviewed in plain-language [27] recommendations, with simple vocabulary, that used short sentences in an active voice and that had a reduced number of complements. The question in this site also required a deep understanding, but the answer was more direct. 
Table 5 .

$\underline{\text { Results of Tasks } 3 \text { and 5. Barrier: Complex text }}$

\begin{tabular}{cccccc}
\hline $\begin{array}{l}\text { Web } \\
\text { site }\end{array}$ & Users group & Time & $\begin{array}{c}\text { Task } \\
\text { completion } \\
\text { rate }\end{array}$ & Emocard \\
\hline NA & $\begin{array}{c}1.1 .1 .1 .1 .1 .4 \\
\text { Expert }\end{array}$ & Novice & $\begin{array}{l}2.19 \\
1.97\end{array}$ & $\begin{array}{c}0 \% \\
29 \%\end{array}$ & Bored \\
\hline \multirow{2}{*}{ A } & 1.1 .1 .1 .1 .1 .5 & Novice & 2.07 & $50 \%$ & Neutral \\
& Expert & & 1.88 & $64 \%$ & \\
\hline
\end{tabular}

Source: The author

Task 3 and Task 5, which were associated with "Complex text", has a more severe impact on participants: they need much more time than in other tasks, and the ratio of success was much lower than in task 1, 2 and 4, as any user could correctly complete these. The mood in the NA-site was "bored" and "neutral" in the A-site. Detailed results are shown in Table 5.

Some of the user comments were, "understanding text is what is most complex to me. I prefer images or videos transmitting the same information, as I understand them much better", and "if the text is difficult and I am very interested in it, I read it three times and I look up the difficult words in a dictionary. But, if I am not very interested or I don't have much time, I skim-read it and I get a general idea of its content".

\subsection{Post-test questionnaire}

After completion of tasks, we asked users about their opinion of which site was more accessible. All of them, without hesitation, preferred the A-Website. Results from the post-task questionnaire are shown in Figs. $4 \mathrm{a}$ and $4 \mathrm{~b}$.

As shown in Fig. 4a, most users identified themselves with negative moods when using the NA site, except two who choose the "neutral" emocard. Contrastingly, moods chosen for the A-site were clearly more positive. Five users identified

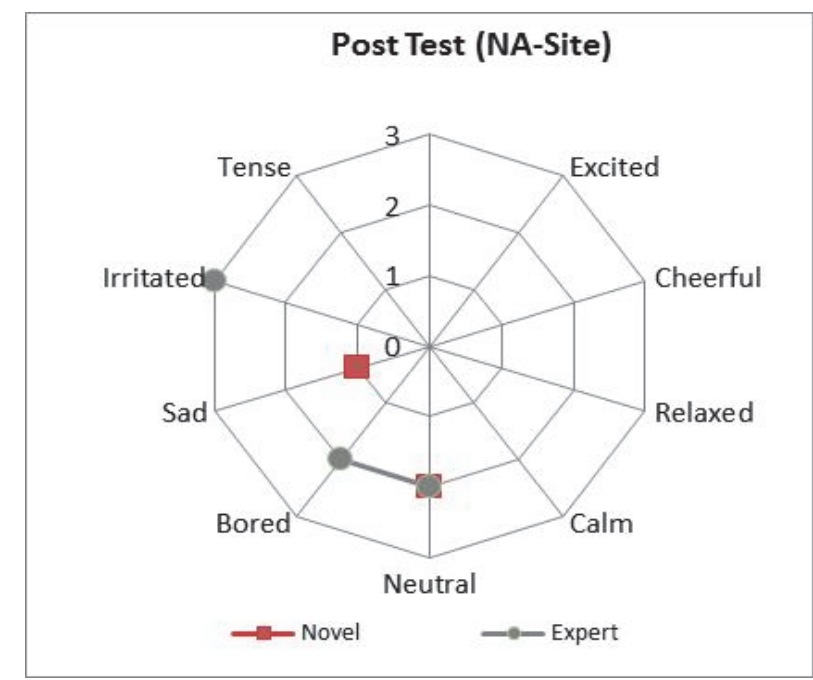

Figure 4a. Emotional evaluation in post-test questionnaire: comparing websites (NA-website).

Source: The author

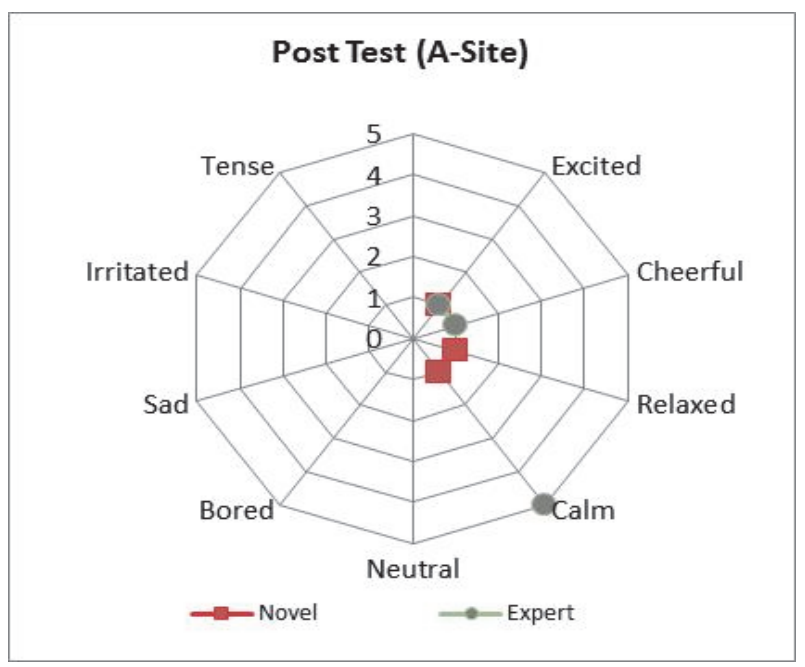

Figure 4b. Emotional evaluation in post-test questionnaire: comparing websites (A-website).

Source: The author

themselves with the "calm" mood for this site that did not have accessibility barriers.

\section{Discussion}

Analyzing the initial user test data we observed some incoherencies between efficiency and effectiveness measures and users' moods. We interviewed the users to be able to understand this mismatch and we discovered that they were not aware of their errors with complex text (T3 and T5).Therefore, we asked them again about their mood, informing them about their performance, and this time they chose a more negative mood. The results presented in the article are based on this second choice.

As we want to base the communication of accessibility errors for web 2.0 users on empathy, we chose to prioritize two barriers "Video with no captions" and "Complex text" as the most impacting ones for users with hearing loss. Regarding the need to include alternatives to audio-visual content, we are completely aligned with WCAG2. However, our prioritization does not fit exactly with WCAG2 on the importance of "complex text", also assessed as very important to this group of users by other authors [31],[32], and -in our view- something that is incompletely covered by WCAG guidelines. Complex text has an AAA priority in WCAG2, and, as a consequence, many laws do not enforce it, as legislation usually sets AA priority as the maximum required level.

The evaluation of emotions is rather difficult, and there are many methodologies available. We are aware that using emocards is a subjective evaluation method and, as such, it is not fully reliable. However, we choose it as a simple measure, which is not completely different from other satisfaction tests.

\section{Conclusions}

The main contribution of this work has been to assess the impact of different accessibility barriers for users with hearing loss. 
As the user tests were conducted with a low number of participants, the results are not statistically valid, but they give hints as to how barriers impact users with hearing impairments. Results from the test demonstrate several aspects that must be taken into account for future research:

- No participant paid attention to the audio element (podcast), as they did not expect any accessibility. Their mood was "neutral"

- Video content, on the other hand, was valued by participants, and they had expectations of captions and signing. In this case moods showed a high arousal.

- Participants were not very receptive to reading tasks, as they acknowledged their own difficulties. Both task 3 and task 5, which were related to the "complex text" barrier, showed a remarkable low level of completion.

In future work, we will tell Web 2.0 users to pay special attention when writing clear text and to include alternatives to video content.

\section{Acknowledgments}

This work was financed by the Improved User Experience for Sustainable Open Government Data Infrastructures (InDAGuS-UX) (TIN2012-37826-C02-02) project, belonging to the Ministry of Economy and Competitiveness, and also by the collaboration agreement signed between ACTIVA MÚTUA 2008 and the University of Lleida. Funding has also been provided by the pre-doctoral grant from the University of Lleida awarded to Afra Pascual.

\section{References}

[1] Alfabetización mediática en el entorno digital. [Online]. Available at: $\mathrm{http} / / /$ europa.eu/legislation_summaries/information_society/strategie s/am0004 es.htm

[2] Informe mundial sobre la discapacidad: Deafness and hearing loss. Organización Mundial de la Salud. Febrero 2014. [Online]. [Date of reference: April of 2014]. Available at: http://www.who.int/mediacentre/factsheets/fs300/en/

[3] García-Perales, F.J. y Herrero-Priego, J., Manual de atención al alumnado con necesidades específicas de apoyo educativo derivadas de discapacidad auditiva. Junta de Andalucía, Consejería de Educación, 2008. [Online]. ISBN 978-84-691-8127-0. [Date of reference: October of 2015]. Available at: http://goo.gl/SYKuA6.

[4] Bandeira, R., Lopes, R., and Carriço, L., Results from multidimensional accessibility assessment. In Proceedings of the $6^{\text {th }}$ international conference on universal access in human computer interaction: design for all and eInclusion -Part I (UAHCI'11), Springer-Verlag, Orlando, USA, pp. 187-196, 2011.

[5] Clark J., To hell with WCAG 2. A List Apart No. 217. 2006. [Online]. [Date of reference: April of 2014]. Available at: http://alistapart.com/articles/tohellwithwcag2

[6] Caldwell, B., Cooper, M., Reid, L.G. and Vanderheiden, G., Web content accessibility guidelines 2.0, December 2008, [Online]. Available at: http://www.w3.org/TR/WCAG20/

[7] Rømen, D. and Svanæs, D., Validating WCAG versions 1.0 and 2.0 through usability testing with disabled users. Universal Access in the Information Society, 11 (4), pp. 375-385, 2012. DOI: 10.1007/s10209-011-0259-3

[8] Bartlett, K., Analysis of WCAG and Section 508 by disability type, 2001. [Online]. The International Center for Disability Resources on the Internet. [date of reference: April of 2014] Available at: http://www.icdri.org/Kynn/disability-comp.html

[9] Pascual, A., Ribera, M. y Granollers, T., Grado de afectación de las barreras de accesibilidad web en usuarios con discapacidad intelectual. In: S.B. and J.U. José Antonio Macías (Eds.), Interacción, pp. 23-26. 2013.

[10] Pascual, A., Ribera, M., Granollers, T. and Coiduras, J.L., Impact of accessibility barriers on the mood of blind, low-vision and sighted users. Procedia Computer Science, 27, pp. 431-440, 2014. DOI: 10.1016/j.procs.2014.02.047. DOI: 10.1016/j.procs.2014.02.047

[11] Brajnik, G., Web accessibility testing with barriers walkthrough. 2006. [Online]. [date of reference: June of 2013] Available at: www.dimi.uniud.it/giorgio/projects/bw

[12] Luckasson, R., Coulter, D.L., Polloway, E.A., Reiss, S., Schalock, R. L. Snell, M.E.; Spitalnik, D.M. y Stark, J.A., Mental retardation: Definition, classification and systems of supports. American Association on Mental Retardation. Washington, D.C. USA. 1992

[13] Rubin, J., Handbook of usability testing: How to plan, design and conduct effective tests. John Wiley\& Sons, NY. USA, 1994.

[14] Schalock, R.L., Hacia una nueva concepción de la discapacidad. Siglo Cero, 30 (1), pp. 5-20, 1999.

[15] Pascual, A, Ribera, M. and Granollers, T., Perception of accessibility errors to raise awareness among web 2.0 users. In Proceedings of the $13^{\text {th }}$ International Conference on Interacción Persona-Ordenador (INTERACCION '12). ACM, New York, NY, USA, 2012. DOI: $10.1145 / 2379636.2379652$

[16] Power, C., Freire, A., Petrie, H. and Swallow, D., Guidelines are only half of the story: Accessibility problems encountered by blind users on the web. In Proceedings of the SIGCHI Conference on Human Factors in Computing Systems. ACM, pp. 433-442, 2012. DOI: $10.1145 / 2207676.2207736$

[17] Lang, P.J., Behavioral treatment and bio-behavioral assessment: Computer applications, 1980.

[18] Cannon, W.B., The james-lange theory of emotions: A critical examination and an alternative theory. The American Journal of Psychology, pp. 567-586, 1987. DOI: 10.2307/1422695

[19] Watson, D., Clark, L.A and Tellegen, A., Development and validation of brief measures of positive and negative affect: The panas scales. Journal of Personality and Social Psychology, 54 (6), pp. 1063-1063, 1988. DOI: $10.1037 / 0022-3514.54 .6 .1063$

[20] Russell, J.A., Weiss, A. and Mendelsohn, G.A., Affect grid: A singleitem scale of pleasure and arousal. Journal of Personality and Social Psychology, 57 (3), pp 493-493, 1989. DOI: 10.1037/00223514.57.3.493

[21] Laurans, G., Desmet, P. and Hekkert, P., The emotion slider: A selfreport device for the continuous measurement of emotion. In Affective Computing and Intelligent Interaction and Workshops, ACII 2009. IEEE, 3rd International Conference, pp. 1-6, 2009. DOI: 10.1109/acii.2009.5349539

[22] Desmet, P., Overbeeke, K. and Tax, S., Designing products with added emotional value: Development and application of an approach for research through design. The Design Journal, 4 (1) pp. 32-47, 2001. DOI: $10.2752 / 146069201789378496$

[23] Desmet, P., Hekkert, P., and Jacobs, J.J., When a car makes you smile: Development and application of an instrument to measure product emotions. Advances in Consumer Research, 27, pp. 111-117, 2000.

[24] Desmet, P., Vastenburg, M.H., Van Bel, D. and Romero, N.A., PickA Mood, Development and application of a pictorial mood-reporting instrument. In: Brassett, J., Hekkert, P., Ludden, G., Malpass, M. and McDonnell, J. (Eds.), Proceedings of the $8^{\text {th }}$ International Design and Emotion Conference, Central Saint Martin College of Art \& Design, London (UK), 2012

[25] López, J.M., Pascual, A., Meduiña, C. and Granollers, T, Methodology for identifying and solving accessibility related issues in web content management system environments. In Proceedings of the International Cross-Disciplinary Conference on Web Accessibility (W4A '12). ACM, New York, USA, 8 P., 2012. DOI: $10.1145 / 2207016.2207043$

[26] Velleman, E. and Abou-Zahra, S., Website Accessibility Conformance Evaluation Methodology (WCAG-EM) 1.0 - 2013. [Online]. Available at: http://www.w3.org/TR/WCAG-EM

[27] Cassany, D., La cuina de l'escriptura. Barcelona: Empúries, 218 P., 1993. ISBN: 84-7596-399-4

[28] Pascual, A., Granollers, T., Ribera, M. and Coiduras, J., Methodology for designing user test environments to evaluate web accessibility 
barriers with disabled users. In the $7^{\text {th }}$ International Conference on Advances in Computer-Human Interactions, ACHI 2014, pp. 103108, 2014.

[29] Rubin, J., Handbook of usability testing: How to plan, design and conduct effective tests. John Wiley\& Sons, NY, USA, 2008

[30] Nielsen, J. and Mack, R., Usability inspection methods. Published by John Wiley \& Sons, New York, USA, 1994. ISBN 0-471-01877-5. DOI: $10.1145 / 259963.260531$

[31] Chung, J.W. Min, H.J. Kim, J. and Park, J.C., Enhancing readability of web documents by text augmentation for deaf people. In Proceedings of the 3rd International Conference on Web Intelligence, Mining and Semantics (WIMS '13). ACM, New York, USA, 10 P., 2013. DOI: $10.1145 / 2479787.2479808$

[32] Inui, K., Fujita, A., Takahashi, T., Iida, R. and Iwakura, T., Text simplification for reading assistance: a project note. In Proceedings of the second international workshop on Paraphrasing - Volume 16 (PARAPHRASE '03), Association for Computational Linguistics, Stroudsburg, PA, USA, pp. 9-16, 2003. DOI: $10.3115 / 1118984.1118986$

A. Pascual, is BSc. degree in Computer Science in 2006, from the University of Lleida, Spain and MSc. in human-computer interaction in 2009, from the same university. She works in usability and accessibility of interactive systems, and her research interests are web accessibility and how to overcome digital accessibility barriers, knowledge filed where she recently obtained her $\mathrm{PhD}$. in Computer Science (UdL, 2015). Is currently undertaking her Ph.D.

ORCID: 0000-0002-2368-755X

M. Ribera, is a BSc. degree in Computer Science from the Universitat Politècnica de Catalunya, Spain and PhD. in digital documentation from the Universitat de Barcelona, Spain. She is currently a professor in the Applied Mathematics Department (MAIA) at the University of Barcelona, Spain. She has worked in the field of digital accessibility for several years, teaching, researching and working on technology transfer. Her specialties are digital document formats. She has also coordinated the official translation of WCAG guidelines versions 1.0 and 2.0 from English to Catalan.

ORCID: 0000-0003-1455-1869

T. Granollers, is a BSc. degree in Computer Science in 1988, from the Autonomous University of Barcelona Spain, and $\mathrm{PhD}$. in Computer Science specializing in human-computer interaction in 2004, from the University of Lleida, Spain. After several years working in different companies as a computer programmer and Project Manager, he is now fully involved in teaching and research activities in the field of human-computer interaction (HCI). $\mathrm{He}$ is currently professor of computer science at the Industrial Engineering Department in the University of Lleida, and director of the Research Group on Human-Computer Interaction and Data Integration (GRIHO) at the same university. As a teacher, he is involved in the first Spanish-speaking HCI Master's and in interfaces design related subjects at other universities and private companies. He is a board member of the $\mathrm{HCI}$ Spanish association AIPO and of the ACM-SIGCHI Spanish chapter, CHISPA. At the GRIHO research group, he also leads and collaborates knowledge and technology transfer projects in industry. Finally, he is coauthor of the book "Diseño de sistemas interactivos centrados en el usuario" published by UOC, 2004.

ORCID: 0000-0001-9189-7308

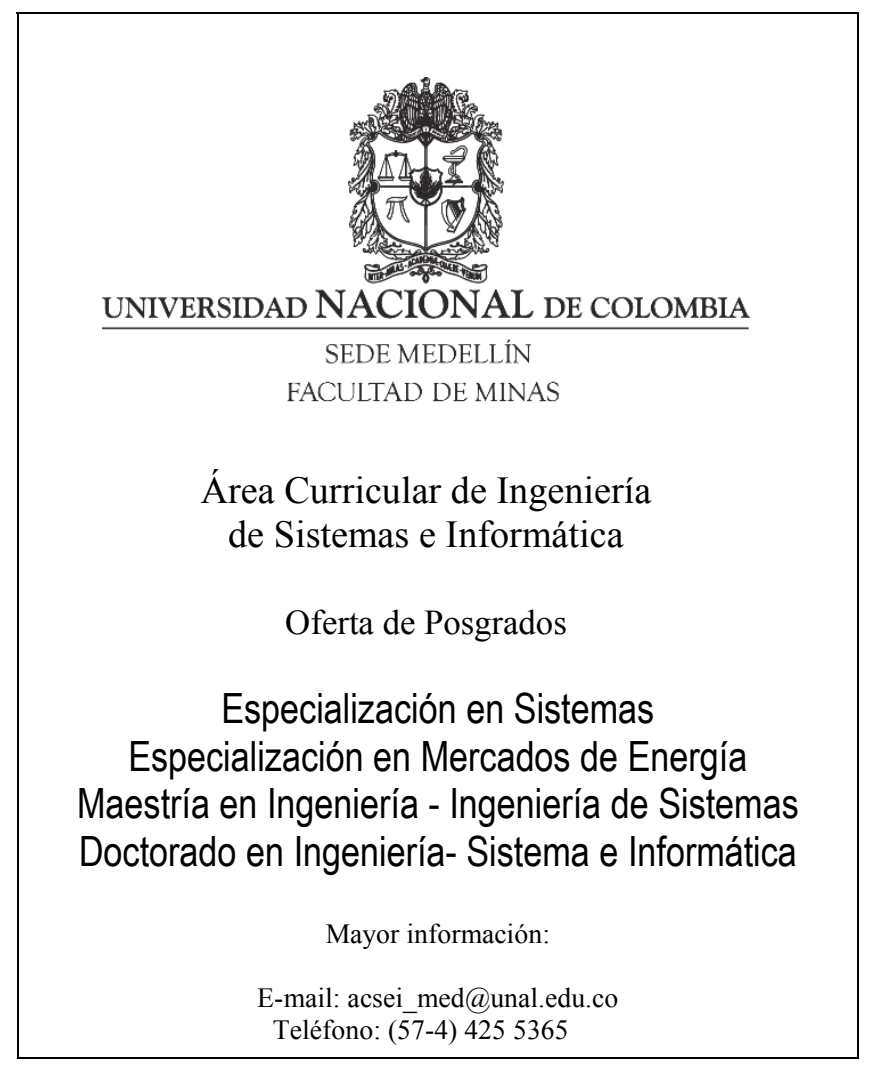

